\title{
MENTAL HEALTH OF CHILDREN AND YOUTH - EXAMPLES OF ACTIONS IN THE AREA OF PREVENTION AND MENTAL HEALTH PROMOTION IN POLISH SCHOOLS
}

\begin{abstract}
The percentage of children and youth in Poland suffering from mental health disorders is significant. Studies and numerous reports on mental health problems in children and adolescents indicate that in recent years the depression has particularly affected people under 18 years of age. WHO data also emphasizes that adolescent suicide is the third cause of death in this age group. The factors determining mental health can be divided into biological and psychosocial. They depend on individual experiences with their families, peers, or schools, as well as on their genetic equipment and brain functions. The mental health situation of children and adolescents in Poland prompted doctors, psychologists, scientific communities, teachers and educators on the one hand to search, analyze and determine the causes of the problems and take action, on the other, to improve the psychophysical condition of young people. The protection of mental health of children and youth in Poland, prevention and promotion of health are recognized as a priority in the health protection policy.
\end{abstract}

Keywords: mental health, child, youth, prevention, promotion, mental health.

\section{Introduction}

Health is one of the key resources that enables a person to develop comprehensively, achieve life goals, fulfill various social roles, and adapt to the changing environmental conditions. A healthy individual has a better chance of self-accomplishment, accomplishments of their own needs and satisfying life. They are better at dealing with difficult situations, making full use of the resources they have. Health "is a state of full, physical, mental and social well-being” (Sokołowska et al., 2015, p. 25).

* PhD Martyna Czarnecka, the Cardinal Stefan Wyszyński University in Warsaw, Poland, Faculty of Education; e-mail: m.zelazkowska@uksw.edu.pl. 
In recent years, due to the high percentage of people suffering from mental health disorders, a lot of attention has been focused on mental health issues as an integral and essential element of health. The World Health Organization (WHO) defines mental health as "a state of mental, emotional, social and somatic well-being in which a person uses their abilities, copes with stress in everyday life, works efficiently and successfully and is able to contribute to the life of a particular community" (Sokołowska et al., 2015, p. 27). Mental health determines the balance between the individual and the environment. It shows the degree of human adaptation to changes taking place in the environment, attitude to self and the world. A mentally healthy person is characterized by a coherent, integrated personality. They are able to respect their abilities and accept limitations.

Currently, many researchers and professionals, when defining health, use the biopsychosocial model, believing that irregularities in functioning in one sphere have negative consequences in the others. It is a complex model that takes into account all dimensions of human functioning, and therefore, it is certainly more useful in determining the mental health of an individual.

Statistical data from the World Health Organization (WHO) indicates that up to $50 \%$ of all mental health disorders originate in adolescence, between the age of 11 and 15/16 (Szymańska, 2012). Statistics show that currently even younger children suffer from mental disorders. Symptoms of mental conditions are diagnosed in newborn infants and children before the age of 10, prior to reaching puberty. Experts in mental health in children and youth report that the frequency of mental health disorders begins in early childhood and reaches its peak during puberty (Namysłowska, 2013; Pawliczuk et al. 2018).

About $10 \%$ of general population of children and adolescents in Poland and in the world exhibit mental health disorders that requires professional help. An increase in the number of cases is being observed, especially in the field of overall developmental disorders, behavioral disorders as well as depressive disorders. The number of suicides committed by young people in Poland in recent years is disturbing, as well as the dramatically increasing number of admissions to adolescent psychiatric wards after suicide attempts or self-harm (Janos-Kozik, 2017). The above data indicates huge needs in the field of mental health protection (Wciórka, 2014).

The high percentage of children and young people suffering from mental health disorders forces reflection on the issue of actions that should be implemented in the field of mental health prevention and promotion. For this reason, both the WHO and the European Union recognize the protection of mental health of children and young people as a priority in health protection policy.

In this paper, the author will present actions implemented in Polish schools in the area of health promotion and disease prevention among school children and youth. Selected preventive programs, recommended by the educational administration (Center for Education Development, Ministry of National Education) will be 
discussed. Schools can receive additional suport from specialised organizations such as mental health services, educational services, or psychiatric centers. The content of this publication is a collection of several different resources: interviews with psychologists and school counsellors from schools where health promotion and disease prevention actions are conducted, and desk research data. Statistical data, reports, publications and professional journals have been analyzed.

The readers should be aware that this article presents only selected mental health promotion and disease prevention action strategies commonly implemented in schools in Poland. The author admits that the article is not a complete account, trusting this text will help readers understand the importance of mental health promotion and disease prevention in schools. The author would also like to add a voice to the discussion on how to improve mental health promotion and disease prevention in Polish schools.

\section{Factors determining mental health}

The state of mental health is shaped by various factors, among which, according to the functional model of mental health, one can distinguish: a state of well-being, individual resources, the ability to establish and maintain satisfactory interpersonal relationships, and coping with difficult situations (Sokołowska et al., 2015). On one hand, the factors can play a protective role, on the other, they can be a risk factor for various risk behaviors and disorders.

The state of well-being is determined by the ability of a person to experience such emotional states that, due to the intensity of emotions, are adequate to the situation being experienced. The content and manifestation of experienced emotions indicate the degree of the accomplishment of one's own needs and motives, which is revealed in the degree of life satisfaction.

Individual resources indicate the beliefs of the individual regarding the perception of self and the world. They are expressed, among others, through selfesteem, efficiency, a sense of coherence, resistance, resilience and life optimism.

The third factor - the ability to establish and maintain satisfying interpersonal relationships - determines the social level of human functioning. It concerns the ability to create and maintain close relationships, cooperation, competition, compromise, use of social support, and activities when social pressure is present.

Coping with difficult situations is closely related to the style of coping with situations of mental discomfort. It concerns both the sphere of thinking expressed in the ability to see ambiguity in perceiving reality, behavior, i.e. the ability to search for effective solutions and their use, as well as emotions, i.e. the ability to identify emotional states and their rational control.

Considering the above, two dimensions of mental health can be assumed: positive and negative. The positive dimension of mental health consists of properties of the individual and their behavior that enable them to cope with difficulties and 
protect man against an illness. The negative dimension increases the likelihood of mental health disorders. Table 1 presents examples of factors characterizing the positive and negative dimensions of mental health, divided into three factors of human functioning: emotional, social and psychological.

Table 1. Sample indicators characterizing the positive and negative dimensions of the mental health of children and adolescents

\begin{tabular}{|c|c|}
\hline Positive dimension of mental health & Negative dimension of mental health \\
\hline \multicolumn{2}{|c|}{ Emotional factor } \\
\hline $\begin{array}{l}\text { - ability to experience and express } \\
\text { emotions } \\
\text { - emotional self-regulation }\end{array}$ & $\begin{array}{l}\text { - lack or low ability to survive and express emo- } \\
\text { tions with frequent „tantrum” behaviors (sudden, } \\
\text { violent reactions, often aggressive, resulting from } \\
\text { helplessness or desperation) } \\
\text { - low level of emotional intelligence development }\end{array}$ \\
\hline \multicolumn{2}{|r|}{ Social factor } \\
\hline $\begin{array}{l}\text { - high social competence (ability to } \\
\text { establish and maintain interpersonal } \\
\text { relationships, prosocial behavior) } \\
\text { - social support and a sense of } \\
\text { belonging } \\
\text { - sense of security and trust in the } \\
\text { world } \\
\text { - ability to set boundaries, assertive } \\
\text { behavior } \\
\text { - positive adult-child relationship } \\
\text { - transparent, clear expectations from } \\
\text { the environment } \\
\text { - positive social norms, respected by } \\
\text { the environment }\end{array}$ & $\begin{array}{l}\text { - low social competences (inability to establish } \\
\text { social relations, lack of pro-social attitudes) } \\
\text { - experiencing peer violence } \\
\text { - lack of social support } \\
\text { - peer rejection } \\
\text { - lack of the sense of security and trust in the } \\
\text { world } \\
\text { - lack of awareness of own borders, submissive } \\
\text { and / or aggressive behavior } \\
\text { - traumatic events } \\
\text { - difficult adult-child relations, lack of authorities } \\
\text { - no clear and transparent social rules, no } \\
\text { consistency }\end{array}$ \\
\hline \multicolumn{2}{|c|}{ Psychological factor } \\
\hline $\begin{array}{l}\text { - positive self esteem } \\
\text { - effective strategies for coping with } \\
\text { stress } \\
\text { - high mental resistance } \\
\text { - autonomy and independence appro- } \\
\text { priate to age } \\
\text { - self-acceptance } \\
\text { - creating opportunities to experience } \\
\text { success and the ability to recognize } \\
\text { your own achievements } \\
\text { - good adaptation skills } \\
\text { - low stress of life }\end{array}$ & $\begin{array}{l}\text { - negative self esteem } \\
\text { - suicidal tendencies, high intensity of depressive } \\
\text { symptoms } \\
\text { - self-harm } \\
\text { - lack of self-confidence } \\
\text { - ineffective coping strategies (alcohol and } \\
\text { drug abuse, truancy, sick leave as an avoidance } \\
\text { strategy) } \\
\text { - low mental resistance } \\
\text { - lack of autonomy and full dependence on the } \\
\text { environment } \\
\text { - no self-acceptance } \\
\text { - exclusive failure, exaggeration of failures wit- } \\
\text { hout the ability to see success } \\
\text { - small adaptation skills } \\
\text { - high intensity of life stress }\end{array}$ \\
\hline
\end{tabular}

Source: own elaboration based on Sokołowska et al. (2015), and Szymańska (2012) 
The protective factors (positive dimension) and risk factors (negative dimension) listed in the table indicate important areas of psycho-preventive and therapeutic work aimed at minimizing the risk of an individual's mental health disorder. In connection with the above, the goal of activities in the area of prevention and health promotion is to strengthen the protective factors and reduce the threatening factors.

\section{Mental health prevention and promotion in Polish schools}

The new core curriculum contains numerous references to the issue of health prevention and promotion. Health education has been given significantly more attention. The regulation on the general education curriculum states that "health education is an important task for schools that need to instill in students the right attitude towards their own health and health of other people's. Students need also understand how to create health-friendly environment" (Woynarowska, 2014, p. 42).

Ministery of National Education (2018) has sent a clear message with interventions that schools should implement to promote mental health among students. Some of the interventions include "pro-social attitude among children and youth, selfesteem, responsibility for one's decisions, assertiveness in challenging situations; student needs-based and problem-based social skills programs and prevention programs; school supervision of how mental health promotion and prevention programs along with other educational actions are implemented; the provision of psychological and educational counselling; supporting students in increasing their self-esteem, providing instructions to students in social and psychological skills to improve students' ability to cope with stressful situations and to build positive relationships with others. All of these topics come from the general education core curriculum for schools and other educational centers."

Schools and teachers may struggle with organizing and implementing health education programs mandated in core curricula. It seems that teachers need to dedicate their time to get involved and collaborate and seek support from their direct school administration.

Before discussing exemplary mental health promotion and prevention activities conducted in Polish educational institutions, one should look at the objectives that are implemented by the above-mentioned strategies.

When characterizing the scope of prevention and health promotion, it is worth reaching for the definitions recommended by the WHO, which indicates that "mental health promotion is about activities aimed at strengthening mental health, well-being and improving the quality of life of entire populations, groups and individuals" (Szymańska, 2012, p. 4). And prevention is about "actions aimed at reducing mental health threats and reducing the number of incidents of disorders" (Szymańska, 2012, p. 4). Despite the fact that both forms of action pursue different goals, their result is focused on one category - reducing mental health threats and improving the quality of human life, by focusing on factors that can be changed 
for the better, e.g. by modifying behavior or equipping with necessary skills and competences. Health promotion and prevention are strategies that complement each other. They are considered interdisciplinary and socio-cultural projects that support the psychological well-being of individuals, groups and communities. Mental health promotion in particular focuses on developing such abilities and competences as expanding self-awareness, building a sense of security, autonomy, adaptability, coping skills, creating lasting relationships, building adequate selfesteem, self-confidence, caring for others, social skills, tolerance (Nowicka, Wzorek, 2017).

Children and youth are the main beneficiaries of mental health promotion and prevention activities. Therefore, it is educational institutions that become the central place where both processes take place.

The WHO has described a four-stage intervention model, promoting various program activities at different levels of intervention in school, depending on the type of problem and its complexity. It breaks the activities into the following areas: the promotion of psychosocial skills, education for mental health, psychosocial interventions and professional therapy.

The Zippi's Friends program and the Epsilon Preventive and Educational Program are among the programs implemented in schools as part of actions for the promotion of mental health These are recommended by the National Bureau for Drug Prevention, the Center for the Development of Education, the State Agency for Solving Alcohol Problems, the Institute of Psychiatry and Neurology in Warsaw.

The Zippi's Friends program is addressed to children between five and nine years of age. It promotes emotional health and is not meant for people with specific mental health problems, but to all children. Its purpose is to improve the emotional functioning of the child, develop personal and social skills. The program teaches how to deal with difficulties and use the skills acquired during classes in everyday life. It also improves the relationship of a child with peers and adults. It is focused on working on specific abilities, such as recognizing feelings and defining strategies for dealing with them, communicating own feelings, making friendships, resolving conflicts, dealing with change and loss.

The Epsilon Preventive and Educational Program is addressed to children from seven to nine years of age as well as educators and parents. The main goal of the program is to develop social skills (e.g. the ability to communicate effectively, building positive peer relationships, non-violent conflict resolution, providing positive information, providing support and assistance to others, developing empathy) and personal skills (e.g. strengthening self-esteem, shaping the awareness of the hierarchy of values, facilitation in coping with difficult situations) of children, as well as to improve the psychosocial functioning of students (e.g. developing teamwork skills and increasing integration in a class team). The program is based on the method of active participation. In particular, narrative techniques such as drama are used. 
The programs implemented as part of mental health prevention activities that are promoted in schools include programs whose main purpose is to counteract and limit the number of attempts to take risky, problematic behaviors of children and young people, to strengthen protective factors and reduce risk factors. Preventive programs are primarily focused on reducing such behaviors as violence, early sexual contact, preventing children and young people from drinking alcohol, delaying alcohol initiation and reducing alcohol problems among teenagers entering adolescence, as well as equipping children with socio-emotional skills (e.g. the ability to cooperate, develop assertive attitudes, notice and recognize emotions) that enable them to function safely in the environment. Examples of programs recommended by the Bank for Preventive Programs implemented in Polish educational institutions include, among others: Home Detective Program that aims at preventing alcohol consumption by young people - a program addressed to children aged 10-12, the Fantastic Opportunities Program is aimed at delaying alcohol initiation and reducing problems of young people entering the adolescence age caused by drinking alcohol, the Treasury Archipelago Program, intended for young people aged 13-16 and aimed at counteracting problematic behavior of young people (prevention of violence, use of psychoactive substances, early sexual contact). The preventive programs described above are only examples of activities implemented in Polish schools, presented in detail on the website created in 2016 and dedicated to recommended preventive programs - www.programyrekomendowane.pl.

It should be added, however, that other projects are also being implemented in schools that are not listed in the Bank of Recommended Preventive Programs, but because of the adopted objectives and assumptions, they are considered good programs that institutions are willing to use. They include, among others: The "I am free from addiction and violence" Program aimed at preventing aggressive behavior and increasing social competence among young people. And the "How to be yourself and resist the pressure of other people" Program, equipping young people with skills that protect them from submission to other peers and knowledge about risky forms of behavior and reasons why it is worth refusing. Among the programs of early prevention, for preschool children groups and early school education, you can choose the "Candy" Program, created in cooperation with the Homo Homini Foundation and the Ministry of National Education. It is based on Agnieszka Grzelak's story "Candy". The basic objectives of this program include: providing children with knowledge about addictive substances and the dangers of using them, developing the ability to notice and name one's own and other people's emotions, strengthening positive self-image, developing cooperation skills, safety in relationships with others and learning assertive attitudes as elements that prevent aggressive behavior. The examples of preventive programs in which the emphasis is on developing social skills and emotional development of the student, building a sense of trust and respect for other people include the "Feel, trust, talk", "Find yourself - the environment and me" Programs. 
The preventive programs are most often run by external specialists who deal with specific issues, but who have had no previous contact with the program beneficiaries.

Currently, there is a tendency among class teachers to design their own scenarios of preventive classes. They adapt the scenarios to the needs and the problems of their students to use during implement them during the homeroom class. Teachers create such activities as part of their own professional development. They appear to have sufficient knowledge, training and self-confidence to discuss health prevention with their students.

Prevention and health promotion are activities that are regularly present in Polish schools but their outcomes need further verification. Nevertheless, they are an important element of everyday educational interactions and are undeniably a huge source of knowledge and support in the proper development of a young person.

\section{Practical recommendations}

School is a place where children not only acquire knowledge, but it is also a place that has a huge impact on their emotional, social and mental development. The student expands their social network, develops social and psychological competences. Schools create opportunities for learning and practicing adult social roles, different from the roles the students' families can offer. By collecting school experiences students can consolidate or verify the image of self, the world and other people.

Schools being responsible for their students' growth, development and education, should not shy away from activities that can protect the students from negative factors occurring in the family and school environment, in relationships with peers that affect children's mental health and youth.

The mental health of children and adolescents depends to a great extent on prevention that is supposed to eliminate the risk factors for mental disorders. Workshops and meetings with experts are systematically conducted in Polish schools to provide children with knowledge, skills and social competences that may be useful in the future. There is no doubt that this is a very important area of activity. Nevertheless, the experience of the teaching staff, author's own observations of the activities and evaluation reports of known preventive programs indicate numerous shortcomings of school prevention programs. Not only are the projects of psychoeducational and psycho-preventive activities of questionable quality but so is the organization of school prevention. The disadvantages of preventive projects also include:

- short-term activities, most often occurring post-factum- promoting secondary prevention;

- implementation of random programs offered to the school; 
- programs funded by local authorities without a prior consultation with teachers who know the needs of their pupils and/or lack of any problem and need assessments;

- $\quad$ workshops taught by external experts with no follow-up consultations;

- improper workshop venue, e.g. a gym, during physical education classes; no information about the date of the workshop, which results in teachers' anger at an external person running the workshop, often disorganizing the work of educators, sometimes at the cost of part or the whole lesson;

- factors related to the school atmosphere (lack of clear rules, consistency and tolerance of teachers towards difficult behavior of children, unwillingness to collaborate, especially when workshops are conducted by out-of-school personnel, teacher conflicts, focus on teaching successes, frequent use of negative reinforcements - punishments, unpleasant atmosphere arousing resentment and fear of school, overcrowded classes) (Szymańska, 2012).

All of the negative aspects of preventive measures implemented in the school environment certainly reduce the effectiveness of even the best-structured programs, Because children cannot fully benefit from the support they are offered, they may be more susceptible to illnesses or other unpleasant social experiences in the future. Hence, the school's task should first be to eliminate the causes of failures, and then to implement effective programs tailored to the needs of students, their development and abilities.

To sum up, mental health is prerequisite for individuals to develop optimally and function properly in every moment of their lives. It is an indispensable capital for the implementation of development tasks and social roles. Therefore, actions aimed at eliminating factors that could threaten mental health become a priority and should be implemented from the earliest stages of human life.

\section{References}

Janos-Kozik, M. (2017). Sytuacja psychiatrii dzieci i młodzieży w Polsce w 2016 roku. Aktualne występowanie i obraz zaburzeń psychicznych wieku rozwojowego. Psychiatry, 1(14).

Kalbarczyk, W. P., Murawiec, S., \& Klabarczyk, M. (2016). Priorytetowe działania w obszarze zdrowia psychicznego na latach 2016-2020. Zadanie finansowane ze środków Narodowego Programu Zdrowia, Warszawa: NPZ.

Namysłowska, I. (2013). Zdrowie psychiczne dzieci i młodzieży w Polsce - stan rozwoju opieki psychiatrycznej i zadania na przyszłość. Postępy Nauk Medycznych, 26(1).

Nowicka, M., \& Wzorek, A. (2017). Szkolny System Wsparcia Zdrowia Psychicznego Program Promocji i Profilaktyki dla szkół ponadpodstawowych. Program powstał w ramach projektu „Myślę pozytywnie” finansowanego przez Ministerstwo 
Edukacji Narodowej ze środków Narodowego Programu Zdrowia na lata 20162020. Warszawa: NPZ.

Pawliczuk, W., Kaźmierczak-Mytkowska, A., Srebnicki, T., \& Wolańczyk, T. (2018). Rozpowszechnienie zaburzeń psychicznych wśród dzieci i młodzieży przebywających w placówkach opiekuńczo-wychowawczych, domach dziecka - przegląd badań epidemiologicznych. Psychiatria Polska, 52(2).

Sokołowska, E., Zabłocka-Żytka, L., Kluczyńska, S., \& Wojda-Kornacka, J. (2015). Zdrowie psychiczne młodych dorostych. Wybrane zagadnienia. Warszawa: Difin.

Szymańska, J. (2012). Ochrona zdrowia psychicznego dzieci i młodzieży w szkole. Warszawa: ORE.

Wciórka, J. (Ed.) (2014). Ochrona zdrowia psychicznego w Polsce: wyzwania, plany, bariery, dobre praktyki. Raport RPO. Warszawa: Biuro Rzecznika Praw Obywatelskich.

Woynarowska, B. (2014). Organizacja i realizacja edukacji zdrowotnej w szkole. Poradnik dla dyrektorów szkół i nauczycieli szkół ponadgimnazjalnych. Warszawa: ORE.

\section{ZDROWIE PSYCHICZNE DZIECI I MŁODZIEŻY - PRZYKŁADY DZIAŁAŃ W OBSZARZE PROFILAKTYKI I PROMOCJI ZDROWIA PSYCHICZNEGO W POLSKICH SZKOŁACH}

Streszczenie: Odsetek dzieci i młodzieży w Polsce cierpiących na zaburzenia zdrowia psychicznego jest znaczny. Badania i liczne raporty dotyczące problemów zdrowia psychicznego dzieci i młodzieży wskazują na rozpowszechnienie w ostatnich latach zaburzeń depresyjnych w populacji osób do 18 roku życia. Dane WHO podkreślają równocześnie, że samobójstwa młodzieży stanowią trzecią przyczynę zgonów w tej grupie wiekowej. Czynniki determinujące zdrowie psychiczne można podzielić na biologiczne oraz psychospołeczne. Są one zależne od indywidualnych doświadczeń człowieka na płaszczyźnie rodzinnej, rówieśniczej, szkolnej oraz wyposażenia genetycznego i funkcjonowania mózgu. Sytuacja zdrowia psychicznego dzieci i młodzieży w Polsce skłoniła lekarzy, psychologów, środowiska naukowe, nauczycieli, pedagogów z jednej strony do poszukiwania, analizowania i określania przyczyn owych problemów, z drugiej zaś do podejmowania działań w kierunku poprawy kondycji psychofizycznej młodych. Ochrona zdrowia psychicznego dzieci i młodzieży w Polsce, profilaktyka i promocja zdrowia, uznawane są za priorytet $\mathrm{w}$ polityce ochrony zdrowia.

Słowa kluczowe: zdrowie psychiczne, dziecko, młodzież, profilaktyka, promocja, zdrowia psychicznego. 